\title{
How to Integrate Spirituality, Emotions and Rationality in (Group) Decision- Making
}

\author{
Volker Kessler
}

\begin{abstract}
This chapter presents a model on decision-making published by Ignatius of Loyola, which integrates spirituality, emotions and rationality. The three different modes are analyzed. Some parallels to modern management advice are shown. The model is then especially applied to group-decision making, which was already done by Ignatius and his "companions of Jesus." I then use the Six Thinking Hats method developed by Edward de Bono, which I adapt in order to integrate the Ignatian model of decision-making.
\end{abstract}

\section{Introduction}

According to Luhmann's theory, “organizations can be designated as decision machines" (Nassehi 2005, p. 85). The German sociologist Niklas Luhmann distinguished three types of decision premises within organizations: (1) decision programs, (2) communication structures, and (3) persons (Luhmann 2011, pp. 222-255). In this chapter we deal with the third type, decisions made by persons.

Ignatius of Loyola (1491-1556), the founder of the Jesuits, reflected in his Spiritual Exercises, on "decision making." He grew up in the beginning of the Modern Era, during which time more options became available, thus offering opportunities for decisions. Ignatius discovered three modes "in which a sound and good choice may be made" (Sp.Ex. 175-177). ${ }^{1}$ Here "good choice" is meant

\footnotetext{
${ }^{1}$ Since the Spiritual Exercises are numbered, the format "Sp.Ex. No" is commonly used for reference. Re the paragraphs Sp.Ex. 175-188, I follow Gallagher's translation, which is based on the Spanish original (Gallagher 2009, pp. 141-144). In the other cases I use the translation given by Louis J. Puhl (Ignatius 1951) spex.ignatianspirituality.com, accessed 12 Dec 2016.

V. Kessler $(\bowtie)$

Akademie für christliche Führungskräfte, Gummersbach, Germany

GBFE, Oerlinghausen, Germany

Department of Philosophy, Practical and Systematic Theology, University of South Africa, Pretoria, South Africa 
spiritually: what does God want me to do? The first mode in discerning God's will is "immediate intuition," where God moves so clearly "that a devout soul will follow without hesitation." The second mode refers to the emotions, and the third mode to the rationalization of the process.

Ignatius' model is worth studying for several reasons: First, it is a model for spiritual decision-making; it integrates spiritual intuition, emotions and rationality in a coherent and structured way. Secondly, Ignatius' preference for relying on feeling more than on thinking challenges the modern Western preference for thinking (cf. O'Sullivan 1990; Moberg and Calkins 2001, p. 263). Thirdly, in his explanatory notes on the third mode, Ignatius gives some practical advice that can be regarded as a forerunner to modern management techniques of decision-making. Fourthly, "the deliberation of the first fathers," which led to the founding of the Jesuit order, is a model of good practice for group decision-making.

This chapter will investigate the three modes and discuss possible applications. It will also point out similarities) between some of Ignatius' advice and modern management techniques. Finally, I will suggest a way to integrate Ignatius' model into group decision-making.

The focus of this chapter is on the three different modes of decision-making (Sp.Ex. 169-189) and their possible applications. This chapter does not deal with spiritual discernment as such, because this is the topic of another chapter. ${ }^{2}$

\section{The Three Modes}

\subsection{The Context}

Ignatius, born as Iñigo López de Loyolas, started his spiritual journey in 1521. During his journey he was confronted with existential decisions, such as whether or not to become a priest. All the while, Ignatius was taking notes, recording insights and "movements" of his soul. He began to distribute this spiritual record because he thought it could help others as well (Knauer 2015, p. 11). The greater part of his originally Spanish text was done by 1541 . With papal approval, a Latin translation was published in 1548. The Spiritual Exercises have in time become fundamental to the Society of Jesus and far beyond. Even Protestants practice the Spiritual Exercises, ${ }^{3}$ despite their battles with the Jesuits since the Reformation. The Spiritual Exercises have also been received outside of theology. For example, Fortemps and Slowinski (2002, p. 109) in their mathematical paper refer to Ignatius' method of decision-making.

\footnotetext{
${ }^{2}$ See the chapter by Patrick Nullens, "From Spirituality to Responsible Leadership: Ignatian Discernment and Theory-U," pp. 185-207.

${ }^{3}$ For example (Kusch 2017, p. 122ff).
} 
A number of books have been written on the Spiritual Exercises, and there are diverse interpretations of this work, the first of which already appeared in the sixteenth century, after the death of Ignatius (Sampaio Costa 2003, p. 75). Modern prominent interpreters are the German Jesuit Karl Rahner and the American Jesuit Jules Toner $(1974,1991)$ with his monumental work on the Spiritual Exercises. ${ }^{4}$ I especially make use of the following publications: the American theologians Christina Astorga (2005) and Timothy M. Gallagher (2009), the Brazilian Jesuit Alfredo Sampaio Costa (2003), the German Jesuits Stefan Kiechle (2008) and Peter Knauer (2015), and the Irish Jesuit Michael J. O’Sullivan (1990).

The Spiritual Exercises have a natural rhythm. Ignatius divided these exercises into four "weeks." This does not necessarily mean calendar weeks but refers rather to phases or movements felt within a person (Sp.Ex. 4). The modes of decision-making are part of the second week, which starts with an introduction to making a choice of a way of life (Sp.Ex. 169). Two fundamental prerequisites are named there:

1. One has a choice between two alternatives which are both good in themselves (or at least not negative) (Sp.Ex. 170)

2. One has a free choice between these two alternatives (Sp.Ex. 171-173)

These prerequisites deal with the ethical issue. If one alternative is ethically good and the other one is ethically bad, then there is no need for a further decision-making process. It is evident that the ethically sound one should be chosen. If one introduces the three modes to an audience without mentioning this fundamental prerequisite, it might lead to an application of the Ignatian process, which would not please Ignatius at all. ${ }^{5}$ People might say: "Well, I know that this decision violates God's commandments, but I had a good feeling doing it and therefore it must be right."

The second prerequisite is necessary because, according to Ignatius, "there are things that fall under an unchangeable choice, such as the priesthood, marriage, etc" (Sp.Ex. 171). "With regard to an unchangeable choice, once it has been made, for instance, by marriage or the priesthood, since it cannot be undone, no further choice is possible," even "if the choice has not been made as it should have been" (Sp.Ex. 172). Nowadays, mainstream Protestant theology would regard neither priesthood nor marriage are "unchangeable." Still, there are choices which are unchangeable. One may for instance decide whether one would like to have children or not, but as soon as one has become a father or mother one cannot simply undo this decision. Some choices in life lead to responsibilities one cannot escape. Parents therefore do not have a real choice "between proper care of their children or additional voluntary activities, no matter how good" (Gallagher 2009, p. 17).

These two prerequisites must be fulfilled in order to apply the following three modes of decision-making (Sp.Ex. 175-178):

\footnotetext{
${ }^{4}$ See, for instance, the review of both in Astorga (2005, p. 89ff), the review of Rahner's interpretation in Waaijman (2002, p. 485, 497f), and the review of Toner's book in Africa (Mugabe 2005, p. 130).

${ }^{5}$ Unfortunately, Gallagher (2009, p. 141) starts with Sp.Ex. 175 and not with Sp.Ex. 170.
} 
Three times in which a sound and good choice may be made.

The first time is when God our Lord so moves and attracts the will that, without doubting or being able to doubt, the devout soul follows what is shown to it, as St. Paul and St. Matthew did in following Christ our Lord. The second time is when sufficient clarity and understanding is received through experience of consolations and desolations, and through experience of discernment of different spirits.

The third time is one of tranquility. ... I said a "tranquil time," that is, when the soul is not agitated by different spirits, and uses its natural powers freely and tranquilly.

If the choice is not made in the first or second time, two ways of making a choice in the third time are given below.

These two ways within the third mode are by (a) weighing the pros and cons of the various options (Sp.Ex. 178-183) or by (b) considering the end, what one would like to have chosen if one were facing death and the day of judgment (Sp.Ex. 184-189); more on this in Sect. 3.

\subsection{Analyzing the Three Modes}

Ignatius locates rational reasoning in the third step, which only becomes relevant if neither of the first two steps has led to a decision (Sp.Ex. 178). Thus the rational option appears as a last resort (Kiechle 2008, p. 29). In my longstanding participation in church board meetings, I have observed that today usually the opposite order is practiced: one starts with rational discourse (mode 3). If and only if this does not work out, one tries to incorporate intuition and emotions, "the gut feelings."

Gallagher (2009, p. viii) uses the following headings for the three $\operatorname{modes}^{6}$ of decision-making:

First mode: Clarity beyond doubting

Second mode: An attraction of the heart

Third mode: A preponderance of reasons

The first mode seems to be the most attractive one because "when God gives this gift, no further discussion is necessary" (Gallagher 2009, p. 82) and there is no need to proceed to the other modes (p. 151). However, even in the Bible records, the first mode is not the typical one. ${ }^{7}$ There were situations where the person involved knew

\footnotetext{
${ }^{6}$ In the Spiritual Exercises Ignatius used the word "time," but in his Autograph Directory he used two words, "time" (tiempo) and "mode" (modo). Gallagher (2009, p. 69ff) opts for the word "mode" and so does Kiechle (2008, p. 27ff).

${ }^{7}$ There are many different opinions on the frequency of the first mode. Some take the extreme view that it is quite rare; others say it is exceptional but not too rare; others say it happens quite frequently, is ordinary. The Ignatian texts say nothing to answer this question (Astorga 2005, p. 79). Based on the Bible records of spiritual experiences, I would argue that it does happen now and then, but not as often as mode 2 or mode 3 .
} 
immediately what to do; for example, the calling of Matthew is reported in one verse (Mt 9:9): Jesus said to him "Follow me," and Matthew rose and followed him. In many other situations in the Old and the New Testament, though, the believers did not know what to do and asked for guidance from God.

At a first glance, one is tempted to label the three modes as:

\section{Immediate intuition;}

2. Emotional process;

3. Rational reasoning.

Then Ignatius' advice in Sp.Ex. 175-177 could be presented as an algorithm:

Start with step 1, spiritual intuition;

If there is no clear spiritual intuition, go to step 2, listen to your emotions;

If the emotions are not clear, go to step 3, use your mind.

However, we have to be cautious about the connotations of the terms "intuition," "emotion" and "rational." When, for instance, I mentioned the three modes to a German business consultant, his spontaneous reply was: "This is well known in marketing. We make our decision by heart (emotions), and then we use our head to rationalize this decision." Although there is some truth to his reply, this message is different from what Ignatius had in mind. The emotions listed by Ignatius are spiritual emotions, i.e. emotions initiated either by the Spirit of God or perhaps by a deceitful spirit (according to the warnings in the New Testament, e.g. 1 Tim. 4:1). Furthermore, Ignatius had a process in mind, with its own possible ups and downs. Thus, these sorts of emotions are to be distinguished from the so-called "affect heuristic" (Kahneman 2011) or from the spontaneous consumerist emotion we might have when we see a new car or a new smart phone for the first time.

In his Spiritual Diary Ignatius described a process he himself underwent (Gallagher 2009, pp. 83-85). The decision to be made was: should he and his companions live in radical poverty? In the first six days, Ignatius felt more inclined to this option; this inclination he interpreted as "spiritual consolations." Later, more troubling experiences entered the process. Mode 2 does not happen in a moment; it requires at least a few days and may in some cases last several months or even years (p. 92).

It is actually the second mode that requires and involves discernment of spirits "for only in this time do we find feelings to be discerned" (Astorga 2005, p. 73). The distinction between consolation and desolation, and openness to both, are crucial to the right application of the second mode. Ignatius understood consolations as "feelings of peace and/or other positive emotions which draw one toward God" (O’Sullivan 1990, p. 5). 
Differences between the modes The following is a comparison of the different modes in order to highlight the specific characteristics of each mode. ${ }^{8}$

First, in mode 1 one has absolute clarity; one is not even able to doubt (Sp.Ex. 175). Conversely, doubt is typical of mode 2 and mode $3 .^{9}$

Secondly, mode 2 is a process that unfolds gradually, sometimes over several months, whereas in mode 1 it happens suddenly.

Thirdly, in mode 1 the person is totally passive while receiving God's gift of clarity. In modes 2 and 3 the person has to be active, either observing his/her emotions over a long period or by weighing pros and cons. "The second and third modes are made available for human effort and striving in decision-making; the first mode is a pure gift from the freedom of God's love" (Astorga 2005, p. 98).

Fourthly, one's emotional state differs from mode to mode. In mode 1 the person experiences "certitude and deep peace." Gallagher (2009, p. 72) reports the experience of Malia, who considered becoming a nun: "There was a sense of great peace and joy and direction. In fact, it was the only time she had experienced such certitude." In mode 2, (strong) emotions can arise, consolations and desolations. Mode 3 requires a calm heart ("tranquil," Sp.Ex. 177), being "indifferent" toward the two alternatives (Sp.Ex. 179). "The third mode is bereft of consolation and desolation, indicating that a different kind of discourse is used to make it distinct from the second and first" (Astorga 2005, p. 87). Gallagher (2009, p. 106) therefore recommends: "If the heart is not calm-is not in a 'tranquil time' - the third mode of discernment should not be attempted."

In spite of the apparently different focuses of modes 2 and 3 it should be noted that mode 2 cannot be reduced to pure affections, nor can mode 3 be reduced to pure rationality. "It is necessary to get beyond a false contrast between a second 'time', arising from affectivity, and a third that is more rational. In different ways, heart and head are present in both these "times"' (Sampaio Costa 2003, p. 87). Mode 2 requires observing and evaluating the emotions. "Such tasks require substantial amounts of

\footnotetext{
${ }^{8}$ Some Ignatian experts deny any real distinction between the modes. Rahner, for instance, regards the three modes as constituting one identical kind of choice. Astorga $(2005$, p. 89) summarizes his position: "All Ignatian discernment of God's will, in his view, is ultimately a second-mode discernment, with the first mode an extraordinary phenomenon whose practical importance is secondary. The third mode is a deficient modality ... the less perfect mode of the second." According to Rahner the third mode is contained in the second mode.

Rahner's interpretation is criticized by Toner (1991) who argues that "Ignatius presented each mode as fully distinct from each other and that each is able to function autonomously as adequate in itself" (Astorga 2005, p. 91). Sampaio Costa (2003) gives further evidence for this position by investigating the Jesuit documents of the sixteenth century. Sampaio especially follows the directory written by Polanco, Ignatius' former secretary, which he regards as "one of the most balanced and illuminating documents we possess illustrating Ignatius' thought" (p. 77). From his investigation Sampaio concludes: "It is important to be able to distinguish what is characteristic of each of the 'times', and to understand their fundamental rationales" (p. 87). I follow this interpretation and will therefore list some differences between the modes.

${ }^{9}$ It is disputed in the Jesuit tradition whether mode 2 or mode 3 will lead to greater certainty (Sampaio Costa 2003, p. 86).
} 
Table 1 Similarities and differences between the three modes

\begin{tabular}{l|l|l|l}
\hline & Mode 1 & Mode 2 & Mode 3 \\
\hline $\begin{array}{l}\text { Time period } \\
\text { Activity of the } \\
\text { person }\end{array}$ & One moment & At least several days & At least several hours \\
\hline $\begin{array}{l}\text { Human } \\
\text { reasoning? }\end{array}$ & No receiving & $\begin{array}{l}\text { Active, observing } \\
\text { emotions }\end{array}$ & $\begin{array}{l}\text { Active, weighing pros } \\
\text { \& cons }\end{array}$ \\
\hline $\begin{array}{l}\text { Heart activity } \\
\text { Doubts }\end{array}$ & $\begin{array}{l}100 \% \text { certitude, deep } \\
\text { peace }\end{array}$ & Affective reasoning & Discursive reasoning \\
\hline Spiritual? & Yes & $\begin{array}{l}\text { Doubts throughout the } \\
\text { process }\end{array}$ & No 100\% clarity \\
\hline
\end{tabular}

cognitive processing and rational judgment" (O'Sullivan 1990, p. 38). Astorga (2005, p. 98) uses the terms "affective reasoning," "judgment of the heart" for the second mode and "discursive reasoning," "operations of the brain" for the third mode.

Modes 2 and 3-sequential or parallel? The advice in Sp.Ex. 176 and 177 reads as if they were to be done sequentially, i.e. mode 3 is only be used if mode 2 does not lead to a decision. Thus the third mode appears as something like a last resort. "You only go to the third 'time' if the second has not brought sufficient light" (Sampaio Costa 2003, p. 85). However, as pointed out by Gallagher (2009, p. 156f), Ignatius himself employed mode 2 and mode 3 in parallel when he had to decide about radical poverty for his society. Thus, although Ignatius presents mode 3 more as a last resort, in practice both modes can be done in parallel. This procedure is also suggested by Kiechle on the basis of his and other people's experiences. Both modes should complement and confirm each other. ${ }^{10}$

All modes are spiritual The distinctions between the modes could give the impression that only the first mode is a truly spiritual one. On the contrary, Ignatius was convinced that God would speak through the consolations and desolations in mode 2 and that God would guide the person's will in mode 3 (Sp.Ex. 180). The decisive criterion when evaluating the different options in mode 3 remains a spiritual one: which option will "be more for the glory and praise of God our Lord and the salvation of my soul" (Sp.Ex. 179)? This is called the Magis principle, i.e., the greater glory principle (Toner 1991, p. 173; Astorga 2005, p. 87). Moreover, both ways of deliberating in the third mode close with bringing the election before God so that He may confirm the choice (Sp.Ex. 183, 188). Thus the whole decision-making process, including all three modes, can be regarded as a "spirituality of choice" (Byron 2008, p. 59) (Table 1).

\footnotetext{
10“Die Erfahrung jedoch zeigt, dass das Entscheiden meist in einer Verbindung aus zweiter und dritter Weise des Wählens zustande kommt. Man prüft Gefühlsregungen und Argumente. . . . Beide Ebenen sollten sich ergänzen, ineinander fließen und sich gegenseitig bestätigen." (Kiechle 2008, p. 29).
} 
No priority Since all modes are spiritual, one should not consider any mode to be better than any other. The wording in Sp.Ex. 178 might create the impression that Ignatius saw the third mode as deficient compared to the other two. Thus it is interesting to note that some of the first-generation followers in the sixteenth century saw the third mode as the safest one (Sampaio Costa 2003, p. 86). ${ }^{11}$ An investigation of the different Ignatian texts on this topic leads Sampaio to the conclusion: "Ignatius had confidence that all three 'times' could lead to a good and healthy Election, and that consequently we were in no position to decide which way was better or safer" (p. 86). As a practical application, Sampaio teaches: "It is not for us to decide which 'time' of Election is be used: we need to accept with humility the 'time' that God chooses to give us" (p. 88).

\section{Forerunner of Modern Management Advice}

Some suggestions within the two ways of making a choice in mode 3 sound like a herald of modern management advice. For instance, Fortemps and Slowinski (2002, p. 109) explicitly refer to the first way of mode 3. I will point out five more similarities. $^{12}$

First, Ignatius taught that "the first point is to place before myself the thing about which I wish to make a choice" (Sp.Ex. 178). Fredmund Malik, one of the most influential management thinkers in German-speaking countries, lists seven steps for a decision-making process (Malik 2006, p. 211). His first step is almost identical to Ignatius' first point: "the precise determination of the problem." One might argue that this first step is just common sense, but Malik (p. 203) explicitly warns against the illusion of assuming that the problem is clearly defined. Ignatius and Malik agree that the first step in a decision-making process must be the identification of the problem.

Secondly, in Sp.Ex. 181 it is suggested that one should list the advantages or benefits and the disadvantages or dangers if one accepts an opportunity, and then should list the advantages and disadvantages if one does not accept this opportunity. By looking at these lists one should notice to "which alternative reason inclines more" (Sp.Ex. 182). In a modern manner of representation this leads to the following $2 \times 2$-matrix, which could be a typical flipchart presentation in a modern group meeting (Table 2).

The scientists Figuiera et al. (2005, p. xii) appreciate Ignatius' "approach of explicitly taking into account the pros and cons of a plurality of points of view." They regard his method as an early example of Multiple Criteria Decision Analysis.

\footnotetext{
${ }^{11}$ Probably this shift occurred because of the fear of the Inquisition which suppressed any trace of illuminism (Sampaio Costa 2003, pp. 76, 78).

${ }^{12}$ O’Sullivan (1990, pp. 28-34) lists some parallels to modern psychological models of decision making.
} 
Table 2 Illustration of Sp.Ex. 181

\begin{tabular}{l|l|l}
\hline & Accept the opportunity & Reject the opportunity \\
\hline Advantages & $1 \ldots$ & $1 \ldots$ \\
& $2 \ldots$ & $2 \ldots$ \\
& $3 \ldots$ & $3 \ldots$ \\
\hline Disadvantages & $1 \ldots$ & $1 \ldots$ \\
& $2 \ldots$ & $2 \ldots$ \\
& $3 \ldots$ & $3 \ldots$ \\
\hline
\end{tabular}

Thirdly, Sp.Ex. 185 reads like advice from a modern book on self-management:

185 ... To look at a man whom I have never seen or known, and, desiring all perfection for him, consider what I would tell him to do and choose for the greater glory of God our Lord and the greater perfection of his soul; and doing myself the same, follow the rule that I propose.

In modern terminology, this is often called "self-coaching" (Dießner 1999), i.e. a person treats himself or herself as a person to be coached.

Fourthly, in the second way of deliberating, Ignatius suggests looking at the alternatives "as if I were at the point of death, what procedure and norm of action I would then wish to have followed in making the present choice" (Sp.Ex. 186). This suggestion is similar to advice from modern management books on imagining one's own funeral: what would the people say about me? (Knoblauch et al. 2007, p. 138). Some authors suggest even writing one's own funeral speech in order to find out: what do I want the people to think about me upon my death? Answering this question will give direction to one's life.

Fifthly, Ignatius distinguished between times for emotion, for reason, for pros and for cons. This is also the basic idea of the "Six Thinking Hats," which will be discussed in the next section.

\section{Group Decision-Making}

\subsection{The Deliberation of the First Fathers}

The well-known "deliberation of the first fathers"13 offers a good example of how to apply these principles to group decision-making. In the year 1539 Ignatius and his other nine "companions of Jesus" lived in Rome to serve the Pope. The Pope then decided to send them into different parts of the world. Thus several questions were on the table: Shall we continue our companionship? If yes, shall we found a religious order? They were all searching for God's will on these questions, but they had diverse opinions (Toner 1974, p. 185). So they took 3 months to find the answers. In

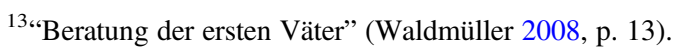


this process they developed new methods for consulting and decision-making within a group. During the day they would pray and think about the decision to be made. At night they would meet for consultation, during which each of them shared his thoughts and feelings about the decision (p. 187). Thus they came to the decision to continue their companionship.

The first question now answered and a decision made, we came to another question more difficult and no less worthy of consideration and forethought. All of us had already pronounced a vow of perpetual chastity and a vow of poverty ... The question was this: would it be advantageous to pronounce a third vow, namely, of obedience to someone from among us ....? (p. 194)

But even after many days the uncertainty about this question remained. The companions then reflected on their initial method of consultation and modified it. In particular, they implemented a procedure for separating the discussions on pros and cons. On one evening they would collect all the reasons against a vow of obedience. "On the next day we argued for the opposite side of the question" (p. 202). The advantage of this method is that the group focuses on one aspect at a time, i.e. they are all looking at the pros and later they are all looking at the cons. This is actually the essential feature of the De Bono method, explained below.

From today's perspective the method of the first fathers was very innovative. But it only became popular after their Superior General Pedro Arrupe, in 1971, encouraged the Society of Jesus to apply this method of the first fathers. It was seen as a good method to work out the participation processes initiated in Vatican Council II.

\subsection{Modern Adaptations of This Method Within the Ignation Tradition}

The American Jesuit Byron (2008, pp. 64-75) has developed a method of group decision-making, which is rooted in the deliberation of the first fathers. ${ }^{14}$ Byron stresses the importance of discernment. As a method he suggests having different times and phases. For example, he would start with laying out the relevant facts; then he would give room for people to express their emotions towards this decision (p. 65). "Before any major decision is made, the decider, in the Jesuit tradition, will want to ask how he or she feels when considering the options" (p. 73). Participants should try to evaluate the source of these feelings: is it the Spirit of God or evil spirits? Then there must be room for listening to God. "This calls for more than just a quick invocation or prayer of petition; the decision-making process has to be laced with a quest for God's will" (p. 66). Byron (p. 68) also suggests separating the discussion of positive and negative arguments, i.e. the pros and cons.

In the Swiss culture, participation and democracy are important values. The Swiss Catholic Waldmüller (2008, pp. 13-17) refers to the deliberation of the first fathers

\footnotetext{
${ }^{14}$ An adapted extract is available on the Internet Byron (n.d
} 
as a good model for participatory processes: "Gemeinsam entscheiden" (deciding together). He applies it to the retreat of a church board (pp. 59-70).

\subsection{Six Thinking Hats}

The idea of structuring the group discussion into different times for facts, emotions, pros and cons is also part of the "Six Thinking Hats," a method published in 1985 by the Maltese author Edward de Bono (1990). As far as I know de Bono never refers to the deliberation of the early fathers as a source. Instead he refers to the Japanese meeting culture (pp. 44-46).

The basic idea of the Six Thinking Hats is that there are six modes of thinking, and at given time the whole group is in the same thinking mode. This avoids the so-called "spaghetti thinking," when for instance one person is thinking about the benefits of an idea, a second person is considering the facts, and a third person is dealing with emotions.

The six thinking hats are distinguished as follows (pp. 31-32):

- The blue hat is concerned with organizing and controlling the thinking process.

- The white hat is concerned with objective facts and figures

- The red hat gives room for the emotions

- The green hat indicates creativity, brain-storming for new ideas.

- The yellow hat reminds us of the sun and looks at the positive aspects of a new idea.

- The dark hat reminds us of the rain and looks at the negative aspects of a new idea.

A possible structure for a group discussion could be as follows:

1. Start with the blue hat, agreeing on the target and the structure of the meeting;

2. White hat: collect the necessary facts

3. If there are strong emotions about the decision, use the red hat to elicit feelings (in a structured manner);

4. Green hat: look for new ideas and collect them;

5. Blue hat: select some ideas which are to be analyzed during this meeting;

6. Yellow hat: list the advantages of the first idea;

7. Black hat: list the disadvantages of the first idea;

8. Yellow hat: list the advantages of the second idea;

9. Black hat: list the disadvantages of the second idea (and so forth ....);

10. Blue hat: Make a decision

Of course, many variations are possible. Sometimes one has to switch to the red hat more often; sometimes it may be necessary to go back to the white hat, because one discovers during the process that important facts are lacking.

Some ideas from the Six Thinking Hats can already be discovered in Ignatius' teaching on decision-making and in the deliberation of the first fathers: separation 
between emotions (red hat) and facts (white hat), separation between listing pros (yellow hat) and listing cons (black hat).

Since 2003, I have been teaching a modified de Bono method. There I use the word "mode/phase" instead of "hat," because the latter is sometimes perceived as childish. This modified method consists of eight modes. I have included a "purple mode," reserved for spiritual aspects, a time for prayer and listening to God's voice. (Furthermore, I split the blue mode into two modes, one for chairing the meeting, one for making the final decision.) This method requires time, at least $90 \mathrm{~min}$, and it requires several flipcharts and pin boards to visualize the facts, the ideas, the pros and cons etc. The participants always appreciate the clarity of the process because the rationale for the final decision becomes very transparent. Many of my students then apply this method in their contexts and later write a report on it. These reports give good evidence for the usefulness of this method.

After this study on Ignatius, I would definitely stress the purple mode in order to give more room for listening to God and spiritual guidance. For example, I would apply the purple mode quite early, to provide room for spontaneous spiritual intuition (mode 1 in Ignatius' model). Perhaps God will speak so clearly to everyone in the group that doubting becomes impossible. If this is not the case, I would then use the red mode after the purple mode so that the participants can share the feelings they had during the purple mode (mode 2). Then I would go on with the more rational modes, i.e. facts (white), pros (yellow) and cons (black). After making the final decision, one could again switch to the purple mode in order to ask God for his confirmation. This would constitute the final point in the Ignatian mode 3 (Sp.Ex. $183,188)$.

\section{Conclusions}

In his Spiritual Exercises Ignatius presented a holistic model for decision-making that integrates spirituality, intuition, emotions and reasoning. An important advantage of his method is the separation between the different modes. The "deliberation of the first fathers" provides a good model for how to apply this method in group decision-making. Their approach has some parallels to de Bono's "Six Thinking Hats." Integrating the Ignatian ideas into the Six Thinking Hats will lead to a method of group decision-making that leaves sufficient room for spirituality, emotions and reasoning. Thus, it will strengthen the nexus between leadership, spirituality and discernment within an organization. 


\section{Bibliography}

Astorga C (2005) Ignatian discernment: a critical contemporary reading for Christian decision making. Horizons 32(1):72-99

Byron WJ (2008) Sharing the Ignatian spirit with friends and colleagues. Loyola, Chicago

Byron WJ (n.d.) A method of group decision making. Making Good Decisions. http://www. ignationspirituality.com. Accessed 24 Aug 2016

De Bono E (1990) Six thinking hats. Penguin, London

Figuiera J, Greco S, Ehrgott M (eds) (2005) Multiple criteria decision analysis. State of the art surveys. Springer, Boston

Fortemps P, Slowinski R (2002) A graded quadrivalent logic for preference modelling: Loyola-like approach. Fuzzy Optim Decis Making 1(1):93-111

Dießner H (1999) Praxiskurs Selbst-coaching. Junfermann, Paderborn

Gallagher TM (2009) Discerning the will of god: an Ignatian guide to Christian decision making. Crossroad, New York

Ignatius of Loyola (1951) Spiritual exercises. Translated by Louis J. Puhl, 1951. http://spex. ignatianspirituality.com. Accessed 12 Dec 2016

Kahneman D (2011) Thinking, fast and slow. Farrat, Straus and Giroux, New York

Kiechle S (2008) Sich entscheiden. Ignatianische Impulse, Echter, Würzburg

Knauer P (ed) (2015) Ignatius of Loyola Geistliche Übungen. Nach dem spanischen Autograph übersetzt von Peter Knauer. Echter Würzburg

Knoblauch J, Hüger J, Mockler M (2007) Dem Leben Richtung geben, 5th edn. Campus, Frankfurt

Kusch A (2017) Entscheiden im Hören auf Gott. Vandenhoeck \& Ruprecht, Göttingen

Luhmann N (2011) Organisation und Entscheidung, 3rd edn. Verlag für Sozialwissenschaften, Wiesbaden

Malik F (2006) Führen, Leisten. Leben. Wirksames Management für eine neue Zeit. Campus, Frankfurt

Moberg DJ, Calkins M (2001) Reflection in business ethics: insights from St. Ignatius' spiritual exercises. J Bus Ethics 33(3):257-270

Mugabe M (2005) Teaching on the discernment of God's will. Reading Jules Toner's Discerning God's will, Ignatius of Loyola's teaching on Christian decision making. In: Kiti PC (ed) Dynamics of the spiritual exercises. African perspectives. Paulines Publ. Africa, Nairobi, pp 129-154

Nassehi A (2005) Organizations as decision machines: Niklas Luhmann's theory of organized social systems. Sociol Rev 53(s1):178-191

O'Sullivan MJ (1990) Trust your feelings, but use your head. Discernment and the psychology of decision making. Stud Spirituality Jesuits 22(4):1-41

Sampaio Costa A (2003) The 'Times' of Ignatian election: the wisdom of the directories. Way 42 (4):73-88

Toner JJ (1974) The deliberation that started the Jesuits. A commentary on the deliberation primorum partum. Stud Spirituality Jesuits VI(4):179-213

Toner JJ (1991) Discerning god's will: Ignatius of Loyola's teaching on Christian decision making. Institute of Jesuit Sources, St. Louis, St. Louis

Waaijman K (2002) Spirituality: forms, foundations, methods. Peeters, Leuven

Waldmüller B (2008) Gemeinsam entscheiden. Ignatianische Impulse. Echter, Würzburg 
Volker Kessler (Ph.D.; D.Th.), holds a Ph.D. in Mathematics, University of Cologne, and a D.Th. in Practical Theology, University of South Africa. For 12 years he worked for the Siemens Company, Munich, as a researcher in cryptography. Since 1998 he is director of the Akademie für christliche Führungskräfte (www.acf.de) and since 2002 he is also dean of the GBFE (www. gbfe.org). In 2012 he was appointed as professor extraordinarius at the Department of Philosophy, Practical and Systematic Theology, University of South Africa. He teaches (Christian) Leadership at different universities and also does professional trainings for business companies and NPOs worldwide. He authored many academic articles and many books, among others the bestsellers Kritisieren ohne zu verletzen and Die Machtfalle, which were re-printed several times and also translated in five other languages.

Open Access This chapter is licensed under the terms of the Creative Commons Attribution 4.0 International License (http://creativecommons.org/licenses/by/4.0/), which permits use, sharing, adaptation, distribution and reproduction in any medium or format, as long as you give appropriate credit to the original author(s) and the source, provide a link to the Creative Commons licence and indicate if changes were made.

The images or other third party material in this chapter are included in the chapter's Creative Commons licence, unless indicated otherwise in a credit line to the material. If material is not included in the chapter's Creative Commons licence and your intended use is not permitted by statutory regulation or exceeds the permitted use, you will need to obtain permission directly from the copyright holder.

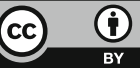

